\title{
Correction to: Effect of enzymatic hydrolysate of cottonseed protein supplementation on growth performance and intestinal health of nursery pigs in Thailand
}

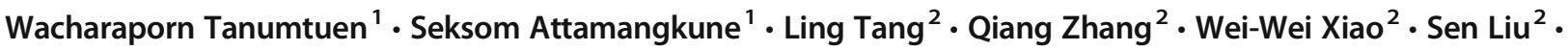 \\ Yuwares Ruangpanit ${ }^{1}$
}

Published online: 17 December 2019

(C) Springer Nature B.V. 2019

\section{Correction to: Tropical Animal Health and Production https://doi.org/10.1007/s11250-019-02078-8}

In the originally published article, the sentence "It was prepared from carefully selected soybean meal and was processed by enzymatic hydrolysis into small peptide." in the section Materials and methods was incorrect.

The correct sentence should read as "It was prepared from carefully selected cottonseed protein and was processed by enzymatic hydrolysis into small peptide."

The online version of the original article can be found at https://doi.org/ 10.1007/s11250-019-02078-8

Sen Liu

liusen@mytech.sc.cn

$\triangle$ Yuwares Ruangpanit ysungwa@hotmail.com

Wacharaporn Tanumtuen Joy_wkt18@hotmail.com

Seksom Attamangkune

agrsea@yahoo.com

1 Department of Animal Science, Faculty of Agriculture at Kamphaeng Saen, Kasetsart University, Kamphaeng Saen, Nakhon Pathom 73140, Thailand

2 Chengdu Mytech Biotech Co., Ltd, Chengdu 610000, China 